\title{
PERBANDINGAN KADAR LOGAM KADMIUM (Cd) DALAM DARAH PEROKOK AKTIF DAN PASIF DI TERMINAL BUS
}

\author{
Betti Rosita $^{1 *}$, Fadhlika Andriyati $^{1}$ \\ Sekolah Tinggi Ilmu Kesehatan Perintis Padang \\ Jalan Adinegoro KM 17 Simpang Kalumpang Padang \\ *Email: bettirosita@yahoo.co.id
}

\begin{abstract}
The high number of smokers in Indonesia is caused by uncontrolled circulation of cigarettes. The danger of smoking does not only occur in active smokers, but also is harmful to passive smokers. Cadmium $(\mathrm{Cd})$ is one of the metals contained in cigarettes that have high toxicity. Cadmium $(\mathrm{Cd})$ is transported in the blood which binds to red blood cells and high molecular weight proteins in the plasma, especially by albumin. The purpose of this study was to determineathe ratio of metal levels of Cadmium $(\mathrm{Cd})$ in the blood of active and passive smokers. Determination of metal content in blood samples by wet destruction method was then analyzed by Atomic Absortion Spectrophotometer (AAS). This type of research is experiment. Based on the results of the study, the lowest ratio of cadmium $(\mathrm{Cd})$ in the blood of active smokers was $0.8 \mathrm{~g} / \mathrm{dL}$ and the highest level was $1.6 \mathrm{~g} / \mathrm{dL}$ while the lowest metal level in the blood of passive smokers was $0.8 \mathrm{~g} / \mathrm{dL}$ and the highest level is $1.4 \mathrm{~g} / \mathrm{dL}$, the highest metal content in the blood of the smoker shows a value that exceeds the normal threshold. From the statistic test, the value of 0.413 was obtained so that $\mathrm{P}>0.05$ so that Ho was accepted, this showed that there was no significant difference between cadmium $(\mathrm{Cd})$ levels in the blood of active smokers and passive smokers in the bus terminal.
\end{abstract}

Keywords: Cadmium, Blood, Active Smokers, Passive Smokers.

\section{PENDAHULUAN}

Indonesia menjadi negara dengan jumlah perokok tersebar di dunia setelah China dan India serta menduduki peringkat ke-lima sebagai konsumen rokok terbesar. Fakta ini memberikan gambaran yang jelas bahwa tingginya jumlah perokok di Indonesia disebabkan oleh peredaran rokok yang tidak terkendali. Penjualan rokok yang bebas di Indonesia memudahkan bagi siapa saja untuk mendapatkannya. Penjualan rokok dapat dilakukan dimana saja. Oleh karena kemudahan memperoleh dan murahnya harga rokok ini, makin banyak orang dapat menjadi konsumen rokok, tidak hanya orang dewasa tetapi juga anak-anak (Witjaksana, 2014). Perokok aktif berisiko untuk terkena kanker hati dan paru, bronchitis kronis, emphysema, gangguan pernapasan, kerusakan dan luka bakar, berat badan rendah dan perkembangan yang terhambat pada bayi. Perokok yang tidak berhenti sebelum berusia 35 tahun memiliki peluang sebesar 50 persen meninggal disebabkan penyakit yang berkaitan dengan rokok (Chotidjah, 2012).

Bahaya rokok tidak hanya terjadi pada perokok aktif saja, melainkan juga berbahaya bagi secondhand smoke yaitu orang-orang bukan perokok yang menghirup asap rokok karena berada di sekitar perokok atau bisa disebut juga dengan perokok pasif (Witjaksana, 2014).

Asap rokok mengandung kimia yang berbahaya pada kesehatan manusia, seperti hydrogen sianida, karbon monoksida dan ammonia. Komponen toksik yang terkandung dalam asap rokok ini bisa menyebabkan kanker, yaitu arsenic, ebenzene, beryllium, kadmium, 
Rosita, B., Andriyati, F. 2019. Perbandingan Kadar Logam Kadmium (Cd) dalam Darah Perokok Aktif dan Pasif di Terminal Bus. Sainstek : Jurnal Sains dan Teknologi. 11 (2) : 70 - 77

ekromium, etilina oksida, nikel, polonium-210, vinil klorids, formaldehid dan sebagainya (Shamsuddin, 2011).

\section{Jenis Penyakit Akibat Bahaya Merokok}

Rokok bukanlah penyebab suatu penyakit, tetapi dapat memicu suatu jenis penyakit sehingga boleh dikatakan merokok tidak menyebabkan kematian secara langsung, tetapi dapat mendorong munculnya jenis penyakit yang dapat mengakibatkan kematian. Berbagai jenis penyakit dapat dipicu karena merokok mulai dari penyakit di kepala sampai dengan penyakit di kaki. Penyakit yang bisa disebabkan oleh merokok adalah seperti sakit kardiovaskuler, penyakit jantung coroner dan kanker seperti kanker paru-paru, kanker mulut, kanker esophagus dan lain-lain lagi (Sitepoe, 2000).

\section{Perokok aktif}

Perokok aktif adalah asap rokok yang berasal dari hisapan perokok atau asap utama pada rokok yang dihisap (mainstream). Dari pendapat di atas dapat ditarik kesimpulan bahwa perokok aktif adalah orang yang rokok dan langsung menghisap rokok serta bisa mengakibatkan bahaya bagi kesehatan diri sendiri maupun lingkungan sekitar (Bustan, 1997).

\section{Perokok pasif}

Perokok pasif yaitu orang yang berada berdekatan dengan perokok yang turut mengisap asap rokok (Sidestream smoke). Seorang perempuan yang mempunyai suami yang mengisap rokok mempunyai risiko yang lebih tinggi untuk mengidap kanker paru berbanding yang tidak merokok.

Perokok pasif atau Second Hand Smoke (SHS) istilah pada orang lain bukan perokok, terpapar asap rokok secara langsung secara tidak sadar dari perokok aktif. Sidestream Smoke (SS) adalah asap rokok sampingan hasil pembakaran rokok itu sendiri sedangkan Mainstream Smoke (MS) ialah asap rokok utama yang dihembuskan kembali keudara oleh perokok aktif. Kedua keadaan ini merupakan masalah penting bagi kesehatan lingkungan terutama di Indonesia, karena meningkatkan pengkonsumsi rokok (Yumaria, 2002).

\section{Logam Kadmium (Cd)}

Kadmium (Cd) adalah logam putih keperakan yang mengkilap dengan berat atom 112,4 dan berat jenis $8,64 \mathrm{~g} / \mathrm{cm} 3$. Kadmium melebur pada $321^{\circ} \mathrm{C}$ (Bradl, 2005). Kadmium tidak larut dalam air, tetapi larut dalam asam, amonium nitrat, dan asam sulfat panas (Moffat, Osselton, \& Widdop, 2011). Logam kadmium telah menjadi permasalahan besar dalam pencemaran lingkungan karena tingkat toksisitasnya sangat tinggi. Rokok merupakan sumber utama paparan kadmium pada manusia (Järup, 2003). Makanan merupakan sumber paparan kadmium terbesar bagi non perokok. Kadmium terakumulasi dalam sayuran hijau, ginjal, liver, dan otot hewan (De Vries et al., 2007).

\section{Toksisitas Logam Kadmium (Cd)}

Kadmium (Cd) merupakan salah satu logam yang terkandung di dalam rokok yang mana belum diketahui fungsinya secara biologis dan memiliki toksisitas yang tinggi. Semakin tinggi kadar dan semakin lama paparan, maka efeketoksik yang diberikan akan lebih besar. Kadmium dapat menyebabkan gangguan saluran pencernaan, sedangkan paparan kadmium dalam dosis rendah tetapi berulang kali bisa mengakibatkan gangguan fungsi ginjal (Kurniawati, Syamsidar, \& Ramadani, 2016).

Kadmium ditransportasikan dalam darah yang berikatan dengan sel darah merah dan protein berat molekul tinggi dalam plasma, khususnya oleh albumin. Secara umum gejala keracunan kadmium pada manusia baik secara akut maupun kronis dapat mengakibatkan gangguan pada sistem pernafasan, kerusakan pada fungsi organ hati dan ginjal, perdarahan, gangguan terhadap pertumbuhan tulang yang menyebabkan kerapuhan tulang. Namun gejala keracunan tidak langsung muncul saat penderita terpapar oleh uap logam Kadmium. Gejala keracunan akut muncul setelah 4-10 jam sejak penderita terpapar oleh uap logam Kadmium. Keracunan logam kadmium dapat menimbulkan paru-paru akut. Penyakit paru-paru akut dapat terjadi apabila penderita terpapar oleh uap kadmium dalam waktu 24 jam. Kejadian yang lebih membahayakan yaitu dapat menimbulkan kematian apabila konsentrasi uap logam 
Rosita, B., Andriyati, F. 2019. Perbandingan Kadar Logam Kadmium (Cd) dalam Darah Perokok Aktif dan Pasif di Terminal Bus. Sainstek : Jurnal Sains dan Teknologi. 11 (2) : 70 - 77

Kadmium berkisar dari 2500-2900 $\mathrm{mg} / \mathrm{m} 3$ (Palar, 2012). Kadmium (Cd) lebih beracun apabila terhisap melalui saluran pernafasan dari pada saluran pencernaan. Kasus keracunan akut kadmium kebanyakan dari menghisap debu dan asap kadmium (Bradl, 2005).

\section{MetabolismeeKadmium (Cd) Dalam Tubuh}

Kadmium ditransportasikan dalam darah yang berikatan dengan sel darah merah dan protein berat molekul tinggi dalam plasma, khususnya oleh albumin. Sebagian kecil kadmium dalam darah mungkin ditransportasikan oleh metalotionin. Kadar kadmium dalam darah pada orang dewasa yang terpapar kadmium secara berlebihan biasanya 1 $\mu \mathrm{g} / \mathrm{dL}$. Absorpsi kadmium gastrointestinal lebih rendah dibandingkan absorpsi melalui respirasi, yaitu sekitar 5-85\%. Absorpsi kadmium akan meningkat apabila terjadi defisiensi $\mathrm{Ca}, \mathrm{Fe}$, dan rendah protein di dalam makanan. Defisiensi $\mathrm{Ca}$ dalam makanan akan merangsang sintesis ikatan Ca-protein sehingga akan meningkatkan absorpsi kadmium, sedangkan kecukupan $\mathrm{Zn}$ dalam makanan bisa menurunkan absorpsi kadmium. Hal tersebut diduga karena Zn merangsang produksi metalotionin (Widowati, Sastiono, \& Jusuf, 2008). Kandungan unsur kadmium dalam contoh asap rokok yang dianalisis ditemukan sangat bervariasi, yaitu antara 0,13 dan 5,40 ppm (Mellawati \& Chichester, 1996).

\section{Darah}

Darah adalah jaringan ikat cair yang terdiri dari cairan kuning pucat, plasma, yang mengandung suspensi sel darah merah atau eritrosit, sel darah putih atau leukosit dan trombosit darah. Komponen darah terdiri dari plasma cair $(60-40 \%)$ dan padat $(40-60 \%)$. Zat padat terdiri dari sel darah merah (eritosit), sel darah putih (leukosit), dan platelet (trombosit). Plasma terdiri dari cairan dengan zat- zat yang terlarut di dalamnya seperti protein, gula, dan garam-garam tertentu. Eritrosit, leukosit, dan platelet di produksi di sumsum tulang belakang, hati, dan limpa. Sel darah merah bertanggung jawab terhadap transpor oksigen. Anemia disebabkan karena kekurangan eritrosit atau molekul pentranspor oksigen yaitu hemoglobin (Priyanto, 2010).

\section{Metoda Destruksi}

Untuk menentukan logam-logam dalam jumlah renik yang terkandung di dalam suatu materi organik, biasanya dibutuhkan perlakuan pendahuluan (pretreatment), sehingga kosentrasi logam tersebut akan menjadi lebih besar. Perlakuan pendahuluan tersebut berguna untuk menguraikan dan merombak bentuk organik dari logam menjadi bentuk anorganik, sehingga material-material pengganggu dapat dihilangkan dan akhirnya logam-logam dapat ditemukan secara langsung dengan menggunakan metode pengukuran tertentu. Destruksi merupakan suatu cara yang dapat dan sering digunakan untuk melarutkan unsur logam dari materi organik yang mengikat logam-logam tersebut. Metode ini ditinjau dari cara dan pereaksi yang digunakan dapat dibagi atas dua cara yaitu destruksi kering dan destruksi basah.

\section{Destruksi basah}

Destruksi basah adalah perombakan zatzat organik yang diperlukan dengan cara menggunakan asam mineral dan zat pengoksidasi dalam larutan. Cara ini terus dikembangkan terutama dalam penentuan logam-logam yang mudah menguap. Karena dengan cara ini suhu pemanasan tidak terlalu tinggi yaitu berkisar antara 100-2000C. Analisis Logam Berat dalam darah digunakan dengan metoda SSA (Spektrofotometer Serapan Atom) adalah suatu alat yang digunakan pada metode analisis untuk penentuan unsur-unsur logam dan metalloid yang berdasarkan pada penyerapan absorbsi radiasi oleh atom bebas dan menggunakan Destruksi basah yaitu pemanasan sampel (organik atau biologis) dengan adanya pengoksidasi kuat seperti asamasam mineral baik tunggal maupun campuran. Jika dalam sampel dimasukkan zat pengoksidasi, lalu dipanaskan pada temperature yang cukup tinggi dan jika pemanasan dilakukan secara kontiniu pada waktu yang cukup lama, maka sampel akan teroksidasi sempurna sehingga meninggalkan berbagai elemen-elemen pada larutan asam dalam bentuk senyawa anorganik yang sesuai untuk dianalisis (Mentar, Kalsum, \& Salmah, 2012). 


\section{METODE PENELITIAN}

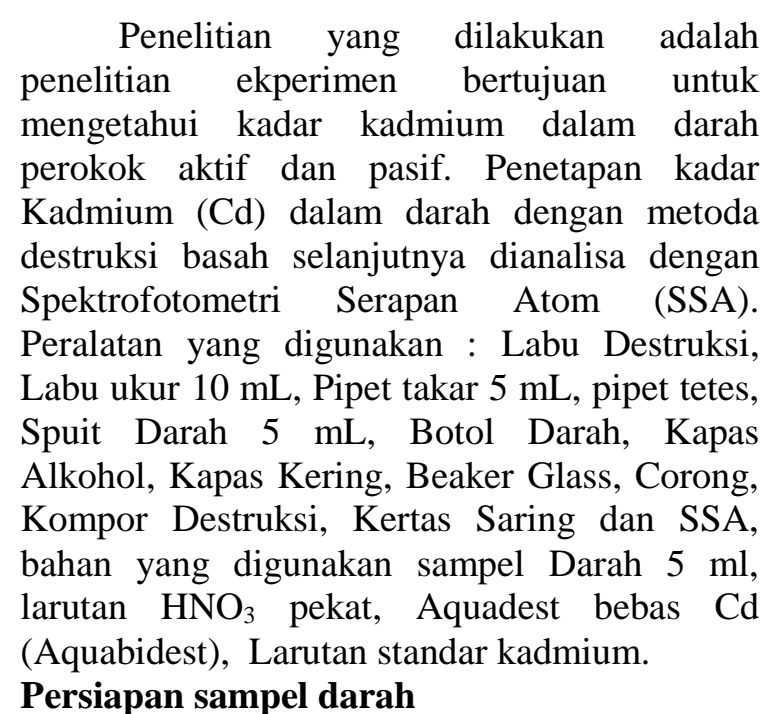

Pengambilan darah vena adalah posisi pasien duduk atau berbaring dengan posisi lengan pasien harus lurus, jangan membengkokkan siku. Pilih lengan yang banyak melakukan aktivitas. Pasien diminta untuk mengepalkan tangan. Pasang "torniquet" $\pm 10 \mathrm{~cm}$ di atas lipat siku. Pilih bagian vena mediana cubiti. Bersihkan kulit pada bagian yang akan diambil darahnya dengan alkohol $70 \%$ dan biarkan kering untuk mencegah terjadinya hemolisis dan rasa terbakar. Kulit yang sudah dibersihkan jangan dipegang lagi. Tusuk bagian vena tadi dengan jarum, lubang jarum menghadap ke atas dengan sudut kemiringan antara jarum dan kulit 15 derajat, tekan tabung vakum sehingga darah terisap ke dalam tabung. Bila jarum berhasil masuk vena, akan terlihat darah masuk dalam semprit. Selanjutnya lepas torniquet dan pasien diminta lepaskan kepalan tangan. Biarkan darah mengalir ke dalam tabung sampai selesai. Apabila dibutuhkan darah dengan antikoagulan yang berbeda dan volume yang lebih banyak, digunakan tabung vakum yang lain. Tarik jarum dan letakkan kapas alkohol $70 \%$ pada bekas tusukan untuk menekan bagian tersebut selama \pm 2 menit. Setelah darah berhenti, plester bagian ini selama \pm 15 menit. Tabung vakum yang berisi darah dibolak-balik kurang lebih 5 kali agar bercampur dengan antikoagulan (Kemenkes RI, 2013).
Sampel darah diambil dari vena lengan menggunakan jarum suntik steril sebanyak 5 ml. Sampel darah dimasukkan ke dalam botol darah yang berisi EDTA sebagai anti koagulan, disimpan dalam suhu $40^{\circ} \mathrm{C}$ dan bisa bertahan dalam waktu sampai 3 minggu.

\section{Pembuatan larutan}

1. Pembuatan Larutan Induk 1000 ppm

2. Pembuatan Larutan Baku Cd 100 ppm

3. Pembuatan Deret Standar 0,2-1 ppm

\section{Pemeriksaan sampel menggunakan SSA}

Pipet $5 \mathrm{ml}$ sampel darah dan masukan ke dalam Labu Destruksi Ditambahkan $5 \mathrm{ml} \mathrm{HNO}_{3}$ pekat, ditambahkan $5 \mathrm{ml}$ aquadest dan destruksi hingga jernih, dinginkan dan masukan sampel tersebut dengan menggunakan kertas saring ke dalam labu ukur $10 \mathrm{ml}$, lalu masukan kembali ke dalam botol vial dan ukur dengan SSA.

Pengukuran larutan standar dengan alat SSA

Penentuan panjang gelombang maksimum dilakukan terlebih dahulu dengan memasang lampu katoda berongga $\mathrm{Cd}$ lalu dihidupkan tombol power pada alat SSA, kemudian diataur lampu sesuai dengan logam yang diinginkan melalui software. Diatur panjang gelombang menurut instruksi manual SSA, logam $\mathrm{Cd}$ dengan panjang gelombang $228,8 \mathrm{~nm}$. Panjang gelombang yang diperoleh pada kurva absorbs maksimum ini digunakan untuk pengukuran konsentrasi logam $\mathrm{Cd}$ dalam sampel.

\section{Analisis contoh uji}

Siapkan instrumen SSA untuk analisa Cd. Lakukan optimasi instrumen hingga siap untuk digunakan. Ukur larutan standar terhadap blanko kalibrasi. Ukur sampel dan spike matriks terhadap blanko sampel.

\section{HASIL DAN PEMBAHASAN}

Kadar kadmium (Cd) dalam darah perokok aktif. Berdasarkan hasil uji laboratorium kadar kadmium dalam darah perokok aktif di terminal diperoleh hasil seperti pada Tabel 1. Berdasarkan Tabel 1 ditunjukkan hasil kadar 
Rosita, B., Andriyati, F. 2019. Perbandingan Kadar Logam Kadmium (Cd) dalam Darah Perokok Aktif dan Pasif di Terminal Bus. Sainstek : Jurnal Sains dan Teknologi. 11 (2) : 70 - 77

kadmium dalam darah perokok aktif yang terendah adalah $0,8 \mu \mathrm{g} / \mathrm{dL}$ dan kadar kadmium yang tertinggi adalah $1,6 \mu \mathrm{g} / \mathrm{dL}$. Kadar kadmium dalam darah yang tertinggi terdapat pada sampel 10 yang berumur 50 tahun dengan lama merokok 30 tahun. Sampel 6 dengan umur 82 tahun lebih rendah dibandingkan dengan yang berumur 50 tahun. Hal ini mungkin terjadi karena beberapa faktor yaitu lama merokok atau paparan logam kadmium ke dalam tubuh selama merokok. Hubungan lama paparan dengan kadar kadmium dalam darah perokok aktif dimaksudkan untuk melihat sejauh mana pengaruh lama merokok dengan kemungkinan terpapar logam kadmium selama merokok. Lama paparan dapat menimbulkan efek yang berat dan bisa berbahaya. Paparan logam bisa terjadi bukan hanya dari asap rokok saja tetapi juga paparan polutan udara yang dikeluarkan oleh emisi kendaraan.

Semakin tinggi konsentrasi partikel logam dalam udara dan semakin lama paparan berlangsung, jumlah partikel yang mengendap di tubuh juga semakin banyak. Berat ringan efek logam tergantung pada proses pemaparan logam yaitu pemaparan secara terus menerus (kontinue) atau terputus-putus (intermitten). Pemaparan terus menerus akan memberikan efek yang lebih berat dibandingkan pemaparan secara terputus-putus (Suciani, 2007).

Kadmium dapat masuk ke dalam tubuh manusia melalui berbagai cara, yaitu dari udara yang tercemar seperti asap rokok dan asap pembakaran batu bara, melalui wadah atau tempat berlapis kadmium yang digunakan untuk tempat makanan atau minuman, melalui kontaminasi perairan dan hasil perairan yang tercemar kadmium, melalui konsumsi daging yang diberi obat anthelminthes yang mengandung kadmium. Kadmium masuk ke dalam tubuh manusia melalui saluran pernafasan, oral dan juga kulit (Fauziah, 2014).

Senyawa kadmium yang terhirup sebagai partikel baik sebagai asap dengan ukuran sangat kecil atau sebagai debu. Setelah paparan inhalasi, penyerapan senyawa kadmium sangat bervariasi dan tergantung ukuran partikel dan kelarutan kadmium tersebut. Besar partikel, debu (>10 $\mu \mathrm{m}$ diameter) cenderung masuk dan menembus ke dalam alveoli. Sementara senyawa kadmium terlarut $\left(\mathrm{CdCl}_{2}\right.$ dan $\left.\mathrm{CdSO}_{4}\right)$ dapat mengalami penyerapan terbatas dibanding dengan partikel. Hanya sekitar 5\% dari partikel $10 \mu \mathrm{m}$ akan disimpan dalam alveoli dan akan diserap. Ukuran partikel merupakan penentu utama penyebab kadmium dapat berada dalam paru-paru.

Pada manusia, 10-30\% debu kadmium akan diserap, 25-50\% akan diserap melalui asap rokok. Kadmium akan masuk melalui saluran pernapasan, diendapkan pada mukosa nasofaring, trakea, bronkus kemudian akan masuk lagi ke alveoli dan alveoli akan diserap oleh darah (Widowati et al., 2008).

Kadmium ditransportasikan dalam darah yang berikatan dengan sel darah merah dan protein berat molekul tinggi dalam plasma, khususnya oleh albumin. Sebagian kecil kadmium dalam darah mungkin ditransportasikan oleh metalotionin (Widowati et al., 2008). Penimbunan kadmium dalam tubuh mengalami peningkatan sesuai usia yaitu dalam tubuh sekitar 20-30 tahun (Dewa, Hadinoto, \& Torry, 2015). 
Rosita, B., Andriyati, F. 2019. Perbandingan Kadar Logam Kadmium (Cd) dalam Darah Perokok Aktif dan Pasif di Terminal Bus. Sainstek : Jurnal Sains dan Teknologi. 11 (2) : 70 - 77

Tabel 1 Hasil Pengukuran Kadmium (Cd) dalam Darah Perokok Aktif

\begin{tabular}{ccccc}
\hline No & Sampel & Umur $($ th) & Lama Merokok (th) & Kadar Cd $(\mu \mathrm{g} / \mathrm{dL})$ \\
\hline 1 & Sampel 1 & 46 & 30 & 1,20 \\
2 & Sampel 2 & 53 & 34 & 0,80 \\
3 & Sampel 3 & 60 & 40 & 1,00 \\
4 & Sampel 4 & 52 & 33 & 1,00 \\
5 & Sampel 5 & 50 & 30 & 0,80 \\
6 & Sampel 6 & 50 & 35 & 1,20 \\
7 & Sampel 7 & 82 & 55 & 1,40 \\
8 & Sampel 8 & 52 & 33 & 1,40 \\
9 & Sampel 9 & 55 & 35 & 1,40 \\
10 & Sampel 10 & 50 & 30 & 1,60 \\
Rata-rata & & & & \\
\hline
\end{tabular}

Tabel 2. Hasil Pengukuran Kadmium (Cd) dalam Darah Perokok Pasif

\begin{tabular}{lcccc}
\hline No & Sampel & Umur $($ th) & Lama Paparan (th) & Kadar Cd $(\mu \mathrm{g} / \mathrm{dL})$ \\
\hline 1 & Sampel 1 & 43 & 31 & 1,40 \\
2 & Sampel 2 & 50 & 32 & 0,80 \\
3 & Sampel 3 & 55 & 35 & 1,00 \\
4 & Sampel 4 & 45 & 35 & 1,40 \\
5 & Sampel 5 & 42 & 35 & 1,20 \\
6 & Sampel 6 & 63 & 40 & 1,00 \\
7 & Sampel 7 & 45 & 35 & 0,80 \\
8 & Sampel 8 & 51 & 39 & 1,40 \\
9 & Sampel 9 & 53 & 35 & 1,00 \\
10 & Sampel 10 & 45 & 35 & 1,08 \\
Rata-Rata & & & & \\
\hline
\end{tabular}

Faktor lingkungan juga mempengaruhi kadar logam di dalam tubuh. Logam berat secara umum masuk ke lingkungan dengan dua cara, yakni secara natural dan antropogenik (terlepas ke lingkungan dengan campur tangan manusia atau tidak alami). Kondisi alami terlepasnya logam berat di lingkungan akibat adanya pelapukan sedimen akibat cuaca, erosi, serta aktivitas vulkanik. Sedangkan, terlepasnya logam berat secara antropogenik akibat aktivitas manusia diantaranya merokok, electroplating/ pelapisan logam, pertambangan, peleburan, penggunaan pestisida, pupuk penyubur tanah, dan lain sebagainya (Ali, Khan, \& Sajad, 2013).

Selanjutnya adalah faktor pola hidup yang sehat. Responden yang memiliki kadar kadmium lebih rendah dapat terjadi karena rutinnya responden tersebut mengkonsumsi air yang cukup, buah dan sayuran yang dapat membuat akumulasi kadar kadmium dalam darah berkurang dan dapat diekresikan ginjal melalui urin.

\section{Kadar kadmium (Cd) dalam darah perokok pasif}

Berdasarkan hasil uji laboratorium kadar kadmium dalam darah perokok pasif di terminal bus diperoleh hasil seperti pada Tabel 2 . Berdasarkan Tabel 2 didapatkan hasil kadar kadmium dalam darah perokok aktif yang terendah adalah $0,8 \mu \mathrm{g} / \mathrm{dL}$ dan kadar kadmium yang tertinggi adalah $1,4 \mu \mathrm{g} / \mathrm{dL}$. Kadar kadmium dalam darah yang tertinggi terdapat pada sampel 1, 10, dan 9 yang berumur lebih rendah dibandingkan dengan sampel 6 yang berumur 63 tahun. Sama halnya dengan kadar kadmium dalam darah perokok aktif, kadar kadmium dalam darah perokok pasif juga dipengaruhi oleh jumlah paparan kadmium dalam tubuh, lama merokok atau paparan kadmium dalam tubuh, cara masuk kadmium 
Rosita, B., Andriyati, F. 2019. Perbandingan Kadar Logam Kadmium (Cd) dalam Darah Perokok Aktif dan Pasif di Terminal Bus. Sainstek : Jurnal Sains dan Teknologi. 11 (2) : 70 - 77

tubuh, faktor lingkungan, dan pola hidup orang tersebut.

Berdasarkan hasil penelitian didapatkan hasil kadar kadmium dalam darah perokok aktif rata-rata $1,18 \mu \mathrm{g} / \mathrm{dL}$ dan perokok pasif rata-rata $1,08 \mu \mathrm{g} / \mathrm{dL}$. Menurut (Widowati et al., 2008) kadar kadmium dalam darah pada orang dewasa yang terpapar kadmium secara berlebihan biasanya $1 \mu \mathrm{g} / \mathrm{dL}$. Hasil penelitian yang didapatkan melebihi nilai ambang batas. Hal ini dapat disebabkan oleh lamanya paparan rokok. Sampel yang didapatkan sesuai dengan kriteria inklusi yaitu dengan lama merokok 30-55 tahun.

Data yang diperoleh sebelum dilakukan uji untuk melihat perbandingan kadar kadmium dalam darah perokok aktif dan perokok pasif tersebut dilakukan distribusi data dengan melakukan uji Shapiro wilk. Secara statistika didapatkan data yaitu terdistribusi tidak normal dengan nilai $\mathrm{P}<0.05$. Kemudian dilakukan uji Mann Whitney Test dimana didapatkan nilai 0.413 maka $\mathrm{p}>0,05$ sehingga Ho diterima dan dapat disimpulkan bahwa hasil menunjukkan tidak terdapat perbedaan diantara kadar kadmium dalam darah perokok aktif dan pasif di terminal kota Padang. Hal ini dapat dikarenakan rutinnya perokok aktif tersebut mengkonsumsi air yang cukup, buah dan sayuran yang dapat membuat akumulasi kadar kadmium dalam darah berkurang dan dapat diekresikan ginjal melalui urin begitu pula dengan perokok pasif sehingga tidak ada perbedaan kadar kadmium dalam perokok aktif dan pasif.

\section{KESIMPULAN}

Berdasarkan hasil penelitian yang dilakukan didapatkan bahwa kadar logam kadmium (Cd) dalam darah perokok aktif yang terendah adalah $0,8 \mu \mathrm{g} / \mathrm{dL}$ dan kadar logam kadmium yang tertinggi adalah 1,6 $\mu \mathrm{g} / \mathrm{dL}$ sedangkan Kadar logam kadmium (Cd) dalam darah perokok pasif yang terendah adalah 0,8 $\mu \mathrm{g} / \mathrm{dL}$ dan kadar logam kadmium yang tertinggi adalah $1,4 \mu \mathrm{g} / \mathrm{dL}$. Tidak ada perbedaan yang signifikan antara kadar logam kadmium
(Cd) dalam darah perokok aktif dan perokok pasif di terminal bus.

\section{DAFTAR KEPUSTAKAAN}

Ali, H., Khan, E., \& Sajad, M. A. (2013). Phytoremediation of Heavy MetalConcepts and Applications. Chemosphere, 91, 869-881.

Bradl, H. (2005). Heavy Metals in the Environment. Germany: ELSEVIER Academic Press.

Bustan, M. (1997). Epidemiologi Penyakit Tidak Menular. Jakarta: Rineka cipta.

Chotidjah, S. (2012). Pengetahuan tentang Rokok, Pusat Kendali Kesehatan Eksternal dan Perilaku Merokok. Makara Sosial Humaniora, 16(1), 49-56.

De Vries, S. J., Van Dijk, A. D. J., Krzeminski, M., Van Dijk, M., Thureau, A., Hsu, V., ... Bonvin, A. M. J. J. (2007). HADDOCK versus HADDOCK: New features and performance of HADDOCK2.0 on the CAPRI targets. Proteins: Structure, Function and Genetics, 69(4), 726-733. https://doi.org/10.1002/prot.21723

Dewa, R. P., Hadinoto, S., \& Torry, F. R. (2015). Analisa Kandungan Timbal $(\mathrm{Pb})$ dan Kadmium (Cd) pada Air Minum dalam Kemasan di Kota Ambon. Majalah BIAM, 11(2), 76-82.

Fauziah, A. (2014). Faktor-Faktor yang Berhubungan dengan Kadar Kadmium (Cd) dalam Urin pada Operator SPBU di Beberapa Wilayah.

Järup, L. (2003). Hazards of heavy metal contamination. British Medical Bulletin, 68 , 167-182. https://doi.org/10.1093/bmb/ldg032

Kemenkes RI. (2013). Pedoman Pelayanan Gizi Rumah Sakit. Jakarta: Kemenkes.

Kurniawati, L., Syamsidar, H., \& Ramadani, K. (2016). Fitoremediasi Logam Kadmium (Cd) dari Asap Rokok Menggunakan Tanaman Puring (Codiaeum variegatum). Al-Kimia UIN Alauddin Makassar, 4(1), 62-67. 
Mellawati, J., \& Chichester, D. (1996). Penentuan Kandungan Unsur Beracun dalam Asap Rokok dengan Metode Pengaktifan Neutron. Presiding Presentasi Ilmiah Keselaniatan Radiasi Dan Lingkungan, 271-277. IAEA.

Mentar, A., Kalsum, \& Salmah, U. (2012). Hubungan Karakteristik Pekerja dan Cara Kerja Dengan Kelelahan Kerja Pada Pemanen Kelapa Sawit di PT Perkebunan Nusantara IV (Persero) Unit Usaha Adolina Tahun 2012. Экономика Региона.

Moffat, A. C., Osselton, M. D., \& Widdop, B. (2011). Clarke's Analysis of Drug and Poisons. Fourth Edition. London: Pharmaceutical Press. Electronic version.

Palar, H. (2012). Pencemaran dan Toksikologi logam berat. Jakarta: Rineka cipta.

Priyanto. (2010). Toksikologi, Mekanisme, Terapi Antidotum dan Penilaian Risiko. Jakarta: Leskonfi.
Shamsuddin. (2011). Pengaruh Asap Rokok. Bandung: Pustaka Grafik.

Sitepoe, M. (2000). Kekhususan Rokok Indonesia. Jakarta: PT Grasindo.

Suciani, S. (2007). Kadar Timbal dalam Darah Polusi lalu lintas dan Hubungannya dengan Kadar Hemoglobin. Universitas Diponegoro Semarang.

Widowati, W., Sastiono, A., \& Jusuf, R. (2008). Efek toksik logam pencegahan dan penanggulangan pencemaran. Yogyakarta: Andi.

Witjaksana, N. (2014). Prospek Keikutsertaan Indonesia dalam Framework Convention On Tobacco Control dalam Kaitannya dengan Upaya untuk Pengendalian Jumlah Perokok Aktif maupun Pasif. Universitas Gadjah Mada.

Yumaria, K. (2002). Panduan Ampuh Berhenti Merokok. Jakarta: TriExs Trimacindo. 